Historic, Archive Document

Do not assume content reflects current scientific knowledge, policies, or practices. 
<smiles>CCCCCCC</smiles> 


\section{SPRING HILL NURSERIES}

Peter Bohlencer \& sons TIPPECANOE CITY

\section{MIAMI COUNTY}

Return in 5 Days to

SPRING HILL NURSERIES

Tippecanoe City, (Miami County) Ohio

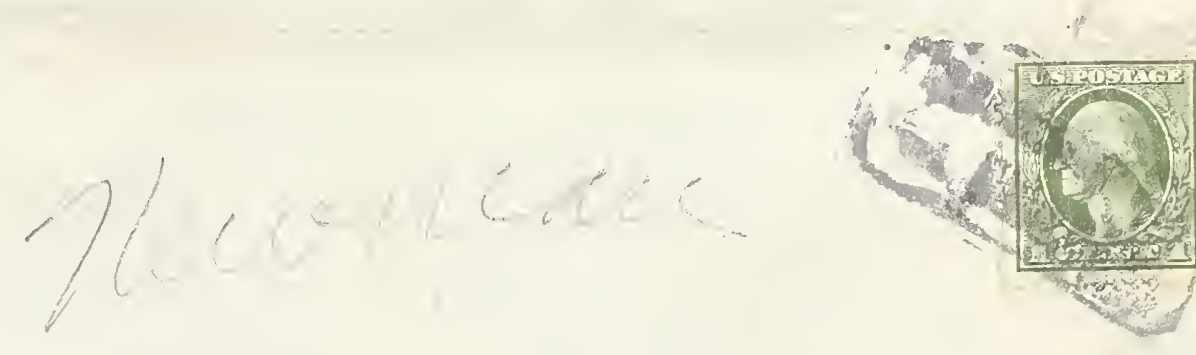
Bereau

a
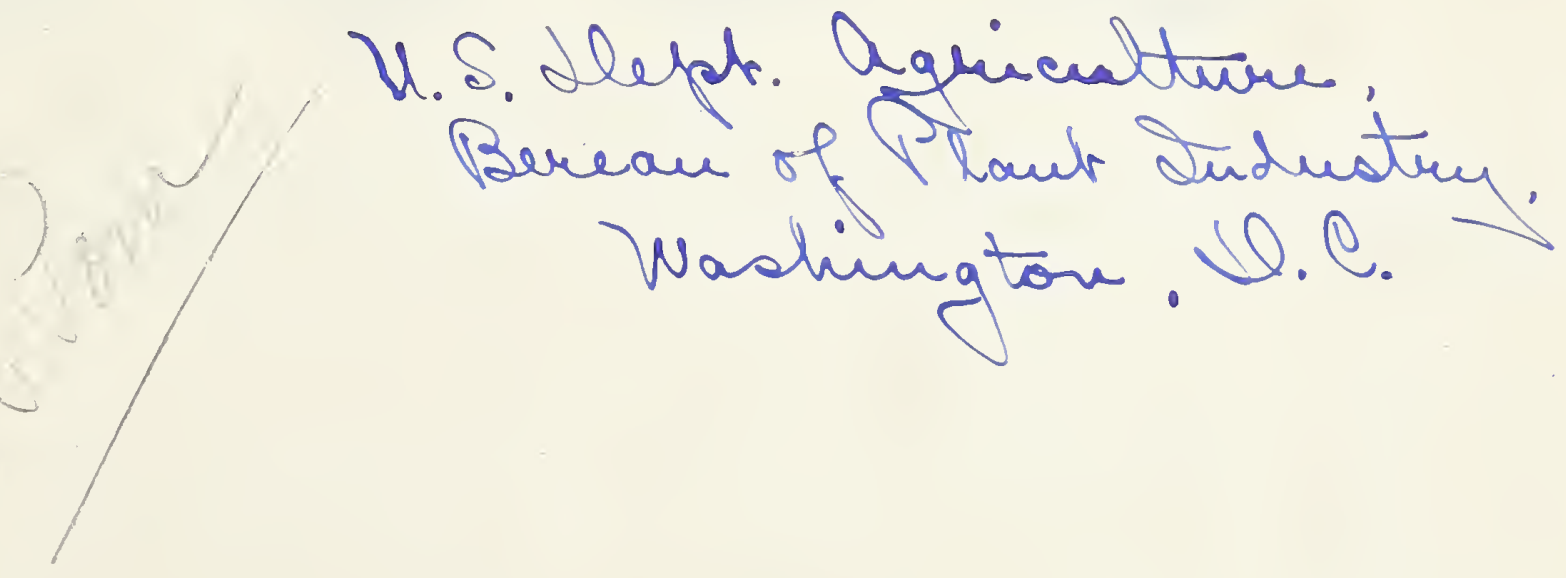

$\mathrm{OHIO}$

This small pamphlet is sent to you for your protection aidd if you will place your order immediately we will reserve the stock for you.

We guarantee that the prices are as good as anywhere else for good clean healthy stock. If there is any drop in the price we will give you the benefit of it. This also protects you from any raise in the price.

The shortage of Nursery Stock in this country is very serious. In our experience of over sixty years in the Nursery business the shortage was never so pronounced and the demand so great. By another year prices will have doubled to what they are at present; and even by Spring they will have advanced very greatly. It will be four or five years before they will again be back to where they are at present.

Read the Editorial in September Sixth issue of the Country Gentleman Published by the Curtis Publishing Co. It will give you facts about this. If you do not want to plant in the Fall place your order for Spring shipment. We will reserve the stock for you, ship it in the Spring of 1920 , in time for planting and you can pay for the stock then if more convenient.

We have more than doubled our efforts to keep up our stock and it has cost us considerably more than usual, but we have the finest stock we have ever produced. When you buy your stock of us you buy the best and if you order early you are sure of getting your stock. 
OUR GUARANTEE specifies to each customer that his order will be filled with good, clean, healthy stckk, well-grown, well-dug, carefully handled and specially selected. If at any time found otherwise than as represented to size, quality or name, stock will be replaced or money refunded. A certificate of inspection accompanies each order.

ORDERS. The same care and attention is given to all orders, whether large or small. It is always advisable to place orders as early as possible; this is especially desired when order is large, so that stock may be reserved for it.

PACKING. Packing is done in boxes or well-protected bales with plenty of damp packing material used. No charge is made for boxes or packing.

REMITTANCE Should Accompany Order. It saves time, chance for error, over-head expense, and means quicker service.

ERRORS. We exercise the utmost care in filling all orders, striving to do a little more than we offer. However, in the press of the season errors will sometimes occur, in which case we shall be glad to make a satisfactory correction, if promptly notified. Please keep a copy of order, for* comparison.

Our book, "What, Where, When and How to Plant" not only tells you and illustrates for you how to plant and care for trees and plants, but also gives you a classified list of varieties to be used for different purposes. The classified list of varieties you will find in the back of the book. Price 10 cents postpaid, or sent free of charge on request with any order sent us.

LOCATION. Our nursery is located on the B. \& O. Railroad and on the Dayton \& Troy interurban line. Our office and packing grounds are one square south of the Dayton \& Troy car barns, and five squares south of the B. \& O. railroad station.

SHIPPING FACILITIES. We can either ship by Parcels Post, freight or express. The B. \& O. sidetrack is within a few feet of our packing sheds, and is our nursery switch. The Dayton \& Troy Traction freight station is within a square of our packing grounds, and we have a private switch within a few feet of our sheds. The Wells-Fargo Company is also convenient. All stock is delivered on board cars at. Tippecanoe City, Miami County, Ohio at the prices quoted here, except where otherwise noted. We make no charges for packing.

\section{Peter Bohlender \& Sons} SPRING HILL NURSERIES, TIPPECANOE CITY, OHIO.

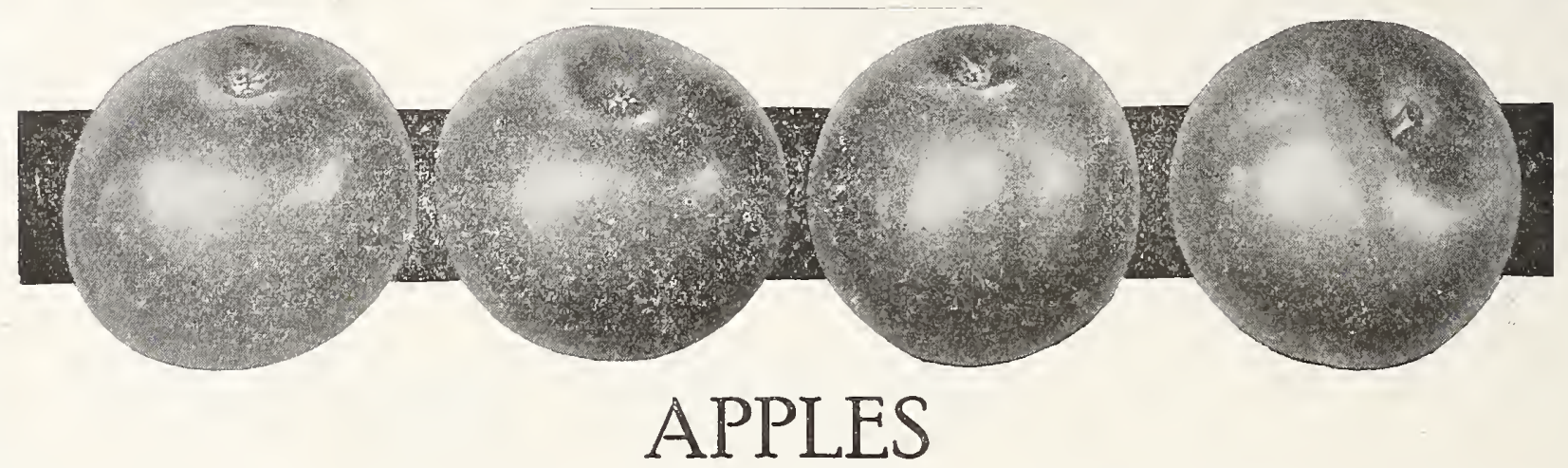

America is the greatest apple producing country in the world. Plant a few trees each season. The ideal soil for apples is a strong loam of a limestone nature but they will thrive on almost any soil, providing it is well drained. Poor drainage will cause the fruit to be of poor quality and flavor.

Our fruit trees are all either budded or grafted. We use only the varieties that give the best results and longest lived trees.

Each Per 10 Per 50

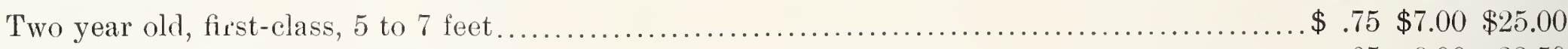

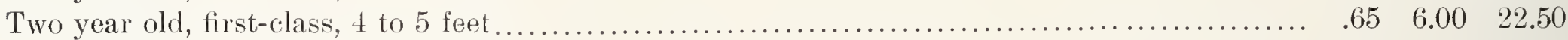

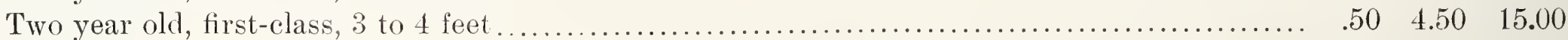

\section{SUMMER APPLES.}

EARLY HARVEST. Medium size; pale yellow. Good for desserts. Ripens in July and August.

RED ASTRACHAN. Medium size. Yellow, red striped. Good market apple. August.

YELLOW TRANSPARENT. Medium, pale yellow. Good cooker. Ripens early in Juiy.

\section{FALL APPLES.}

DUCHESS. Large fruit. Yellow, striped red. Fine for cooking. September.

FALL RAMBO. Fine for eating. Medium size. Yellow, striped red. October.

MAIDEN'S BLUSH. Large size; red spotted. Excellent for home and market. August. October.

WEALTHY. Large, bright red. Bears young and good keeper.

\section{WINTER APPLES.}

ARKANSAS BLACK. Large, reddish black. Flesh yellow and delicious. Good keeper. December to April.

BALDWIN. Large, bright red. Good for market and home use. December to March.

BANANA. Large, clear yellow. Fine aromatic flavor. Good market apple, but will not stand long shipping. November to February.

DELICIOUS. Brilliant dark red shaded to yellow; flesh crisp, fine grained and juicy. Good keeper and shipper. April.

BEN DAVIS. Large, red striped. Never fails. January to

WE PREPAY EXPRESS OR FREIGHT CHARGES ON ALL ORDERS OF \$3.00 OR MORE EAST OF THE MISSISSIPPI RIVER.
GANO. Improved Ben Davis. Large, red. Good keeper. Very productive. December to March.

GRIMES GOLDEN. Medium size. Pale yellow. Fine for market and a good producer. November to February.

JOHNATHAN. Medium size, yellow, flushed with red. Flesh juicy and tender and of excellent quality. November to March.

MAMMOTH BLACK TWIG. Large, showy, dark red apple of good quality. November to April.

McINTOSH RED. Fruit medium to large. Flesh tinged with yellow and often veined with red. Crisp and juicy and almost sweet, when ripe. October to December.

NORTHWESTERN GREENING. Large, greenish yellow; good flavor. Good keeper. January to June.

NORTHERN SPY. Large, striped crimson. Retains juicy, rich qualities until late Spring. January to June.

ROME BEAUTY. Trees come into bearing early. Fruit large, handsome; yellow with crimson cheek. Flesh tender and juicy. November to February.

STARK. Large, golden green with crimson shadings. Yellow flesh. January to May.

STAYMAN'S WINESAP. Medium size. Flesh juicy and highly flavored. No apple is more widely planted. November to April.

WINESAP. Medium dark red. Flesh yellow, crisp and richly flavored. December to March.

YORK IMPERIAL. Medium sized, smooth, waxon-yellow fruit, flushed with carmine. Good keeper. December to February.

\section{CRAB APPLES}

TRANSCENDENT. Largest and best of the Siberian Crab. The fruits are about one and one-half to two inches in diameter. Bright yellow, striped with red; flesh crisp and juicy. August to September. 


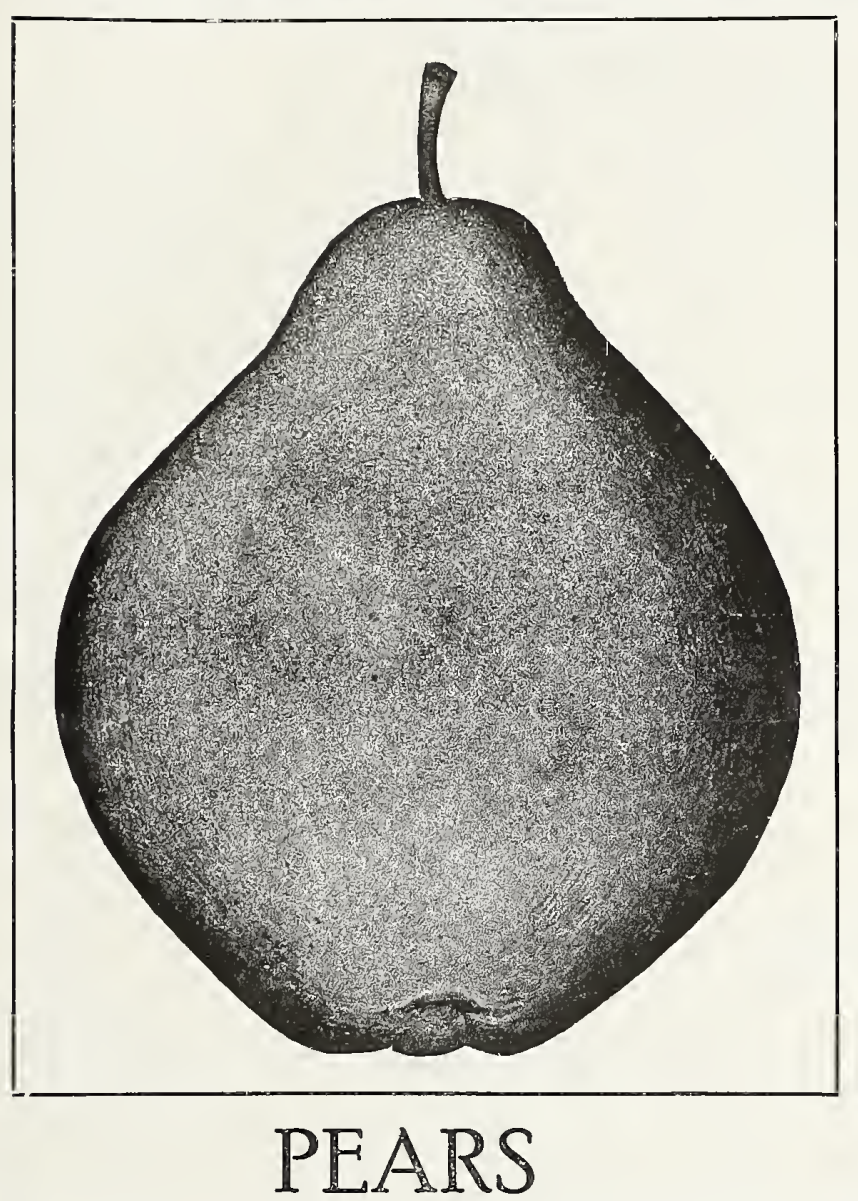

Our pear trees are of the finest quality for transplanting, for they are well developed stocky trees. A strong loam of moderate depth or a dry subsoil, is best adapted to the pears, but they arlapt themselves to as great a variety of soil as will any other fruit. The soil should not be too rich, as a too rapid growtl is more likely to produce blight. ALL FIRST CLASS TREES

Each Per 10 Per 50 2-year old, 5 to 7 feet.

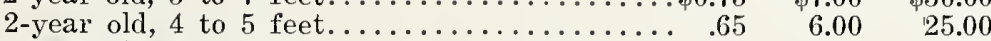

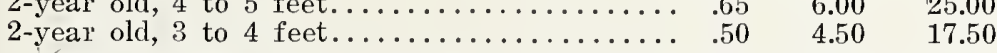

BARTLETT. Large, handsome, waxon yellow with red blush Flesh rich, juicy and highly flavored. One of the best varieties for canning. August and September.

CLAPP'S FAVORITE. Fruit large, long, yellow, spotted dull red. Flesh fine grained and juicy. August.

DUCHESS D'ANGOULENE. Large, dull greenish yellow. Flesh white, juicy and well flavored. A profitable market variety. October and November.

FLEMISH BEAUTY. Fruit large; skin pale yellow; flaror sweet and melting. September and October.

KIEFFER. Fine for canning and preserving. Trees are not troubled with scale and seldom fail to bear a good crop. Trees bear young. October and November.

SECKLE. Rich, delicious flavor. Very popular for dessert. August and September

KOONCE. Exceedingly hardy, almost frost-proof; will bear heavy crops when other varieties are destroyed by frost. Handsome pear of medium size. July and August.

SHELDON. A pear of the very finest quality; rich and highly aromatic. Greenish russet with red cheek. September.

\section{DWARF PEAR TREES.}

The fruit of the dwarf pear is the same quality as that of the standard and the same soil and treatment may be accorded them Where space is limited they are much to be desired as they do not occupy so much space. These pears differ from the standards in as much as they are propagated on quince stock, which makes them slow growing and dwarfish.

The varieties are: Duchess, Flemish Beauty, Bartlett, Clapp's Favorite and Kieffer. For description of any of these varieties see the same varieties under Standard Pear.

\section{PRICES OF DWARF PEARS}

3 to 4 feet. Each Per 10 Per 50

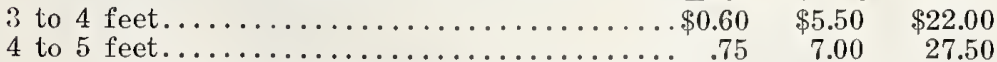
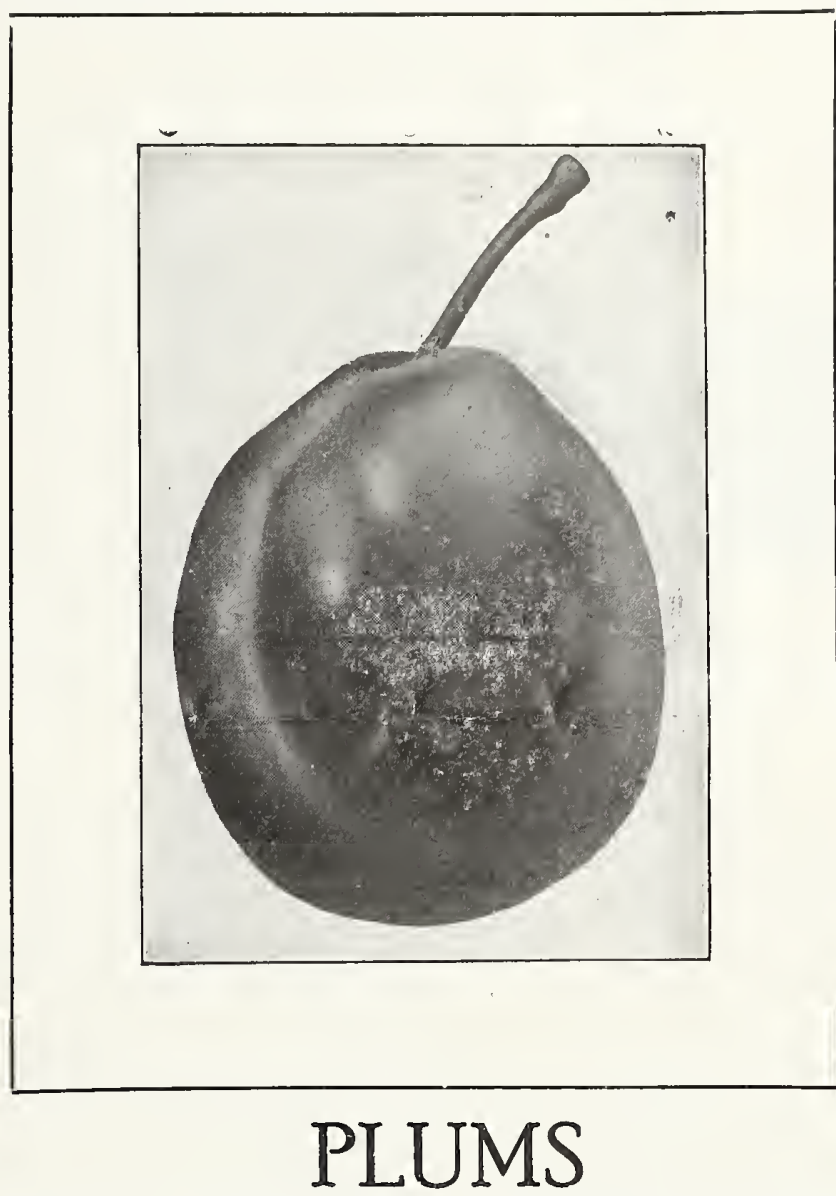

The market demand for high grade plums is almost unlimited, and for dessert, cooking and canning no fruit is more delicious.

A light sandy soil is preferred for plums but they do well on almost any well drained soil. The trees should be sprayed annually.

BRADSHAW. Very large, dark violet red. Flesh yellow, juicy and good. Valuable market variety. Middle of August.

$\checkmark$ BURBANK. Very large, cherry red. Flesh yellow, sweet and firm. Fine for keeping and shipping. August.

GERMAN PRUNE. Large, purple fruit that is firm, sweet and delicious. A freestone. September.

LOMBARD. Medium size, oval, violet red. Flesh yellow and juicy. Good market variety-adheres to the stone. Late August.

MOORE'S ARCTIC. Purplish black plum. Fruit small to medium; flesh juicy, sweet and richly flavored. August.

REINE CLAUDE. Large, roundish oval fruit of greenish-yellow color, spotted with red. Flesh yellow, juicy, rich and of good quality. Very productive.

SHIPPER'S PRIDE. Large, showy plum, frequently 2 inches in diameter. Flesh sweet and firm. Good shipper. September.

YELLOW. EGG. Yellow, egg shaped plum of large size. Yellow flesh which clings to the stone. Late August.

\begin{tabular}{|c|c|c|c|}
\hline & Each & Per 10 & Per 50 \\
\hline to 4 feet. & $\ldots \$ 0.60$ & $\$ 5.50$ & $\$ 22.50$ \\
\hline feet. & . $\quad .75$ & 7.00 & 30.00 \\
\hline feet & .. $\quad .85$ & 8.00 & 35.00 \\
\hline
\end{tabular}

\section{Order Now! We guarantee prices will not be less; but much} higher before Spring. Send us your order now and we will ship then at present prices if you do not wish to plant this Fall. 


\section{CHERRIES}

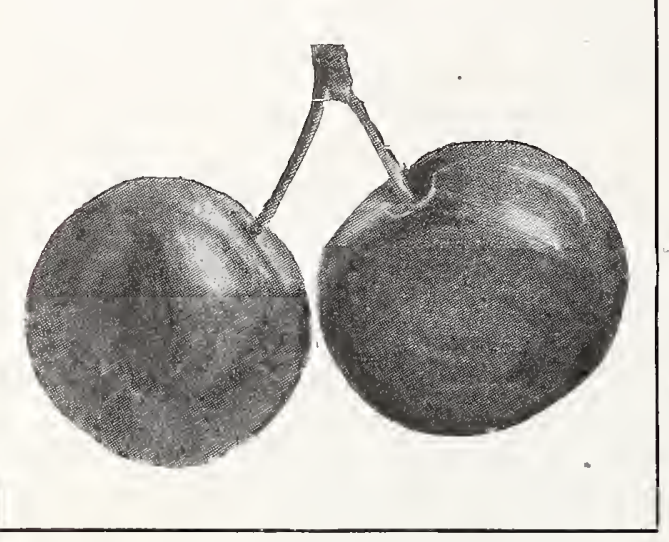

Cherries are excellent for commercial orchards, as the fruit is always in demand at high prices. Cherries are infected by fewer diseases than any other fruit trees. The scur varieties are never troubled with scale and are easily grown wherever apple: succecd.

BLACK TARTARIAN. Bcautiful, purplish cherry, of superb quality, rich and juicy. Prolific bearer and erect groweì. Lače Jun` and Iuly.

DYEHOUSE. Fruit medium sizc, sofi red and juicy. Tree very hardy, upright grower and very productive. June.

EARLY RICHMOND or MAY. Fres grow- er and reliable producer. Fruit is medium, dark red, juicy and has an acid flavor. June. GOVERNOR WOOD. A standard sweet cherry. Light red fruit and does not rot easily. Trce is stout, healthy grower and an abundan't bcarer. June.

LARGE MONTMORENCY. One of the very besi of the sour cherries. Fruit large, dark red and handsome. Good producer and shippei', June.

WINDSOR. Large delicious sweet cherry of a reddish brown color. Valuable for late market $\mathrm{O}_{z}$ home use. July.

YELLOW SPANISH. Large, handsome sweet cherry with light red cheek. Firm and delicious. Late June.

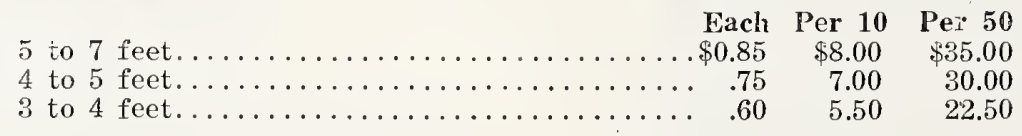

\section{PEACHES}

A deep sandy loam, that is well drained, is best suited to peach trees. Before transplanting the trees be sure to trim off every branch close to the tree and cut back the stem of the tree itself about one-third. To have a perfectly formcd, round headed tree, they should be trimmed each year. All our varieties are budded on high class stock and are thrifty, well rooted trees that will give good results.

BELLE OF GEORGIA. Large free-stone peach with red cheek, red through the fine white flesh to the seed. July.

CARMEN. Large, freestone, flesh creamy white, tender, rich and juicy. A fine shipper. August.

CHAMPION. Fine freestone peach. Large, creamy white, flesh white, rich and juicy. August.

CRAWFORD'S LATE. Similar to Crawford's Early, but ripens two or three weeks later.

CRAWFORD'S EARLY. Very large, rich yellow freestone of the finest quality. Trees are very productive. Late August.

CROSBY. Medium size, bright yellow with carmine. Flesh yellow with good flavor. Freestone. September.

ELBERTA. Large with golden yellow skin, covered with crimson. Flesh yellow and good. Great canning peach, also good shipper. Freestone. August and September.

ENGLE'S MAMMOTH. Late yellow, resembles the Late Crawford but is more productive. September.

HEATH CLING. Fruit very large, creamy white with a faint blush. Flesh pure white to the stone, juicy and sweet. Popular for preserving and canning. Good keeper. October.

NIAGARA. Large, golden yellow freestone. Good shipper and canner.' Early August.

\section{QUINCE}

The Quince is always in demand, although its commercial value seldom changes. It is a reliable cropper and requires little care. The trees thrive in almost any soil, but prefer a heavy, moist, clay loam.

CHAMPION. Trees bear when only two years old. Large oval fruit of rich color and excellent quality.

APPLE or ORANGE. Large, round bright golden-yellow. Very good flavor which makes it valuable for preserving. One of the finest late varieties.

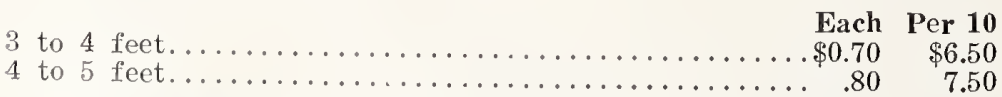

J. H. HALE. Large, deep golden yellow with bright carmine. Smooth. Flesh firm, perfect freestone. Ripens a little before the Elberta. August and September.

FITZGERALD. Fruit is bright yellow, large; flesh deep yellow, firm and of high quality. Freestone. Late August.

KALAMAZOO. Fruit large, golden yellow with a crimson cheek. Flesh yellow. Delightful flavor; freestone. Trees bear early. September:

LEMON FREE. Large fruit, light yellow with a greenish tinge; flesh golden yellow, tender and juicy. Excellent for canning.

OLD MIXON FREE. Standard, late white peach. Large, handsome freestone with tender, excellent, white flesh. Early September.

SMOCK. Large, yellow peach, mottled with red. Juicy frecstone. Valuable market variety. Late September.

SALWAY. Large dull yellow, mottled with brownish red. Flesh yellow; freestone.

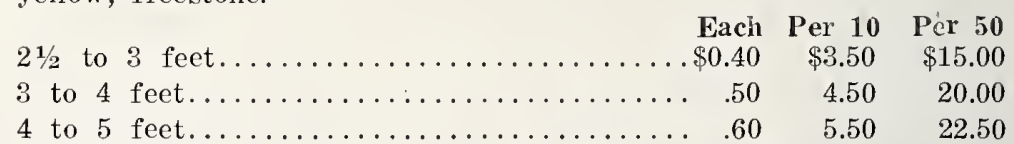

\section{MULBER RIES}

\section{R USSI A N - A very} hardy, rapid growing tree and very productive.

Each $.50 \mathrm{c}$ 


\section{GRAPES}

AGAWAM. Large, compact, dark red berries. Ripens early and is very attractive.

BRIGHTON. Very desirable, early red grape. Medium to large sized bunches; good flavor and quality.

CATAWBA. Medium large red grape of good quality. Late.

CAMPBELL'S EARLY. One of the strongest growers and a most hardy variety. Good quality and long keeping.

CONCORD. Most popular black grape in America. Good shipper, sweet and juicy. Vine hardy, healthy and productive.

DELAWARE. An American grape. Small fruit, compact bunches. Delicately flavored. Pink flesh.

MOORE'S EARLY. Very popular, early grape. Hardy and a good grower.

NIAGARA. Berrìies greenish yellow. Leading white grape for home and market use.

POCKLINGTON. Berries golden yellow, sweet and juicy. Vine hardy and a good producer. Good shipper.

SALEM. Strong, vigorous vine. Large berries are dark copper color, and very sweet with a thin skin. Early September.

WORDEN. A seedling of the Concord. Large bunches which ripen 10 days earlier than the Concord.

WYOMING. Vine very hardy, healthy and robust. Berries are beautiful light red; flesh tender, sweet and juicy. Best early red market grape.

VERGENNES. Large, white amber berries are rich and delicious and hold firmly to the stem. An excellent keeper.

WOODRUFF RED. A very profitable grape when grown with the Delaware. Good shipper and keeper. Very vigorous and a good producer.

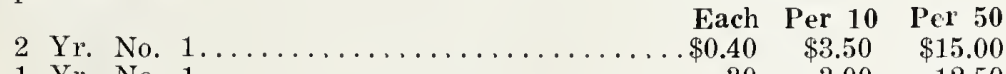

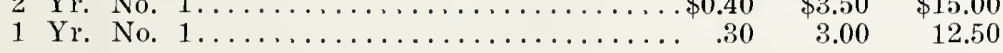

\section{CURRANTS}

Large, two year old, first-class plants. 40 cents each; $\$ 3.50$ per ten; $\$ 15.00$ per fifty.

Strong, one year old, first-class plants, 30 cents each; $\$ 2.50$ per ten; $\$ 10.00$ per fif $: y$.

CHERRY. Bush a strong grower, very hardy and prolific bearer, large bright berrics with thick skin and fine flavor.

FAY'S PROLIFIC. Leading market currant. Long stems, fine flavor and very productive. Fruit easy to pick; good shipper. Plants very hardy.

RED CROSS. Medium sized, bright red berries, borne in long clusters and are of fine quality.

WILDER. Upright and vigorous glower, bright red berry of excellent quality. Largely planted by the best fruit growers.

\section{Gooseberries}

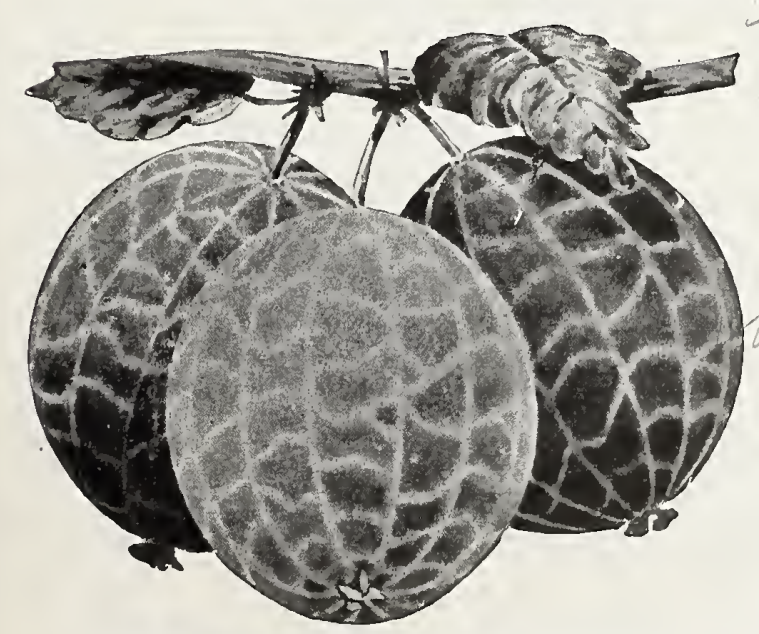

DOWNING.-

Medium sized fruit; flesh soft and juicy; a very good market berry. 30c Each.

\section{HOUGHTON-} Very productive, good and vigorous grower. An old and reliable variety. Very hardy. $30 c$.
RASPBERRIES

Small fruits are easily raised and seldom miss a crop. They give big returns for the time and money spent on them. We are offering nothing but the varieties that are known to be the very best on the market.

GREGG. Large, showy, black, firm and will ship well. Hardy and vigorous grower; ripens about mid-season.

HAYMAKER. Very large, firm berry; one of the best for home use. Plants are very hardy and a good crop may be depended upon each year. Good shipper.

CUMBERLAND. Fruit is largest of all the black caps. Good shipper and one of the most profitable as a market berry.

CUTHBERT. Fruit is large, dark crimson, sweet, rich and as highly flavored as strawberries.

ST. REGIS. A very healthy grower that bears a good quality of bright berries throughout the entire season.

KING. A very red berry that always commands a good price. This variety is earlier than any other.

Per 25 Plants $\$ 1.50 \quad$ Per 100 Plants $\$ 4.00$ Per 1000 Plants $\$ 30.00$ St. Regis-Per 25 Plants, $\$ 2.50$; Per 100 Plants, $\$ 7.50$

\section{Blackberries}

EARLY HARVEST. Best early blackberry in cultivation. Fruit firm and of good quality, excellent shipper; good market variety.

ELDORADO. Fruit is very large, good quality and jet black Good shipper and a great producer. We personally recommend this variety above any other that is offered.

MERSEREAU. Yields enormous crops of brilliant, black berries that retain their color under all conditions.

SNYDER. Medium size and one of the best known varieties of the blackberries, succeeding wherever planted.

Per 25 Plants $\$ 1.50$ Per 100 Plants $\$ 4.00$ Per 1000 Plants $\$ 30.00$

\section{STRAWBERRIES}

We prefer to offer Strawberries for Spring planting. $\$ 10.00$ per $1000 ; \$ 1.50$ par 100 . Good assortment of varieties. Everbearing Strawberries for Spring planting.

\section{ASPARAGUS}

An early vegetable, with the healthful qualities and can be easily grown in well drained, rich soil. It depends more on
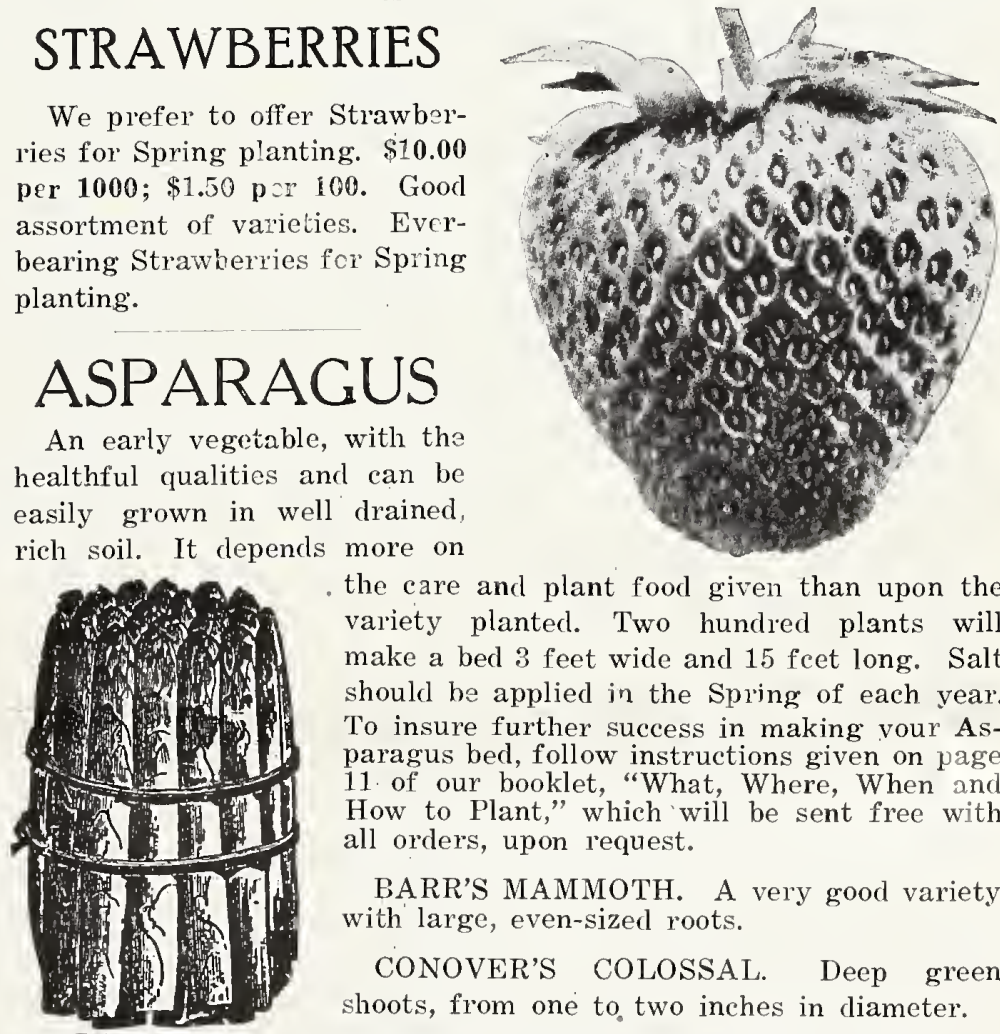

the care and plant food given than upon the variety planted. Two hundred plants will make a bed 3 feet wide and 15 fcet long. Salt should be applied in the Spring of each vear. To insure further success in making vour Asparagus bed, follow instructions given on page 11. of our booklet, "What, Where, When and How to Plant," which will be sent free with all orders, upon request.

BARR'S MAMMOTH. A very good variety with large, even-sized roots.

CONOVER'S COLOSSAL. Deep green shoots, from one to two inches in diameter.

PALMETTO. Noted for its large sized and beautiful stocks. It is often on the market several days before the other varieties.

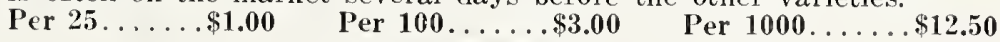

\section{RHUBARB OR PIEPLANT}

LINNAEUS. Leaf-stocks, long, large, tender, juicy, produced quite early. Cellar-grown rhubarb with beautifully pink tender stalks may be enjoyed in March by any one who will devote a little time to it. For this crop the plants are grown from spring until fall in very rich soil so as to establish a number of crowns on each root. In the fall a number of roots are packed together with rich soil in some cool, dark cellar. After the crop has been cut, the roots are replaced in the garden to regain their vigor for the next year's forcing.

Each................10c. Per 12............\$1.00

WE PREPAY EXPRESS OR FREIGHT CHARGES ON ALL ORDERS OF \$3.00 OR MORE EAST OF THE MISSISSIPPI RIVER. 


\section{WEEPING TREES}

ACER (Maple.)

-SACCHARINUM var. Wieri (Wier's Cut-leaf Weeping Maple.) Branches are pendulous and leaves are deeply cleft, giving almost a fern-like appearance. 8 to $10 \mathrm{ft} . \ldots \ldots \ldots \ldots \ldots \ldots \ldots \ldots \ldots \ldots \ldots \ldots \ldots \ldots . .25$

BETULA (Birch.)

-ALBA var. Pendula Lanceolata (Cut-leaf Weeping Birch.) A beautiful tree with tall, slender, drooping branches and delicately cut leaves. Its white trunk and branches make it attractive in winter. 5 to 6 feet...........\$1.00 6 to 8 feet...........\$1.50 MORUS (Mulberry.)

-ALBA var. Tartarica Pendula (Tea's Weeping Mulberry.) We recommend tlis as one of the hardiest and most beautiful of the weeping trees. The slender, willowy branches, which sweep the ground, form a beautiful tcnt of green. 2 yr. heads...............\$2.00

\section{ORNAMENTAL TREES}

There is nothing more beautiful than an Ornamental Tree. They complete the landscape and protect your winter home from the wintry winds and save many a ton of coal.

\section{ACER (Mapie.)}

-NEGUNDO (Box Elder, Ash Leaf Mrple.) A large spreading tree of rapid growth; very hardy and a good drought resister. Lergely planted for windbreaks and timber.

6 to 8 feet...........50e 8 to 10 feet.........\$1.00 - PLANTANOIDES (Norway Maple.) A large, handsome tree with a compact head of spreading branches. The broad, deep green leaves cast a dense shade.

6 to 8 feet..........\$1.00 8 to 10 feet........\$1.25 -SCHWEDLERII (Purple-leaved Norway Maple.) One of the most beautiful of the shade trees. In early Spring the young leaves are bright red, changing to purplish green as they grow older. 6 to 8 feet...........\$1.50 8 to 10 feet.......... $\$ 2.50$ -SACCHARUM (Sugar Maple, Rock Maple.) Long lived; grows well, except in damp, soggy soils. An excellent street and shade tree of upright, dense growth.

6 to 8 feet...........75c 8 to 10 feet...........\$1.00 -SACCHARINUM (Soft Maple, Silver Maple.) An ornamental tree with wide, slender, spreading branches. Thrives almost anywhere, but grows very rapidly in moist, rich soil.

8 to 10 feet............75c

10 to 12 feet.

.$\$ 1.00$

CATALPA.

BUNGII (Umbrella Catalpa.) An ornamental tree with a broad, dome-shaped head and a long, straight stem. When it attains ful growth, the top is often 15 to 20 feet in diameter and not over 3 to 4 feet tall. 5 to $7 \mathrm{ft} .2$ yr. old heads................... $\$ 1.50$

\section{FRAXINUS (Ash.)}

-AMERICANA (American White Ash.) A handsome, hardy and broad-headed, quick growing shade tree, sometimes reaching a height of 120 feet. Valuable for park and street planting.

6 to 8 feet............75c 8 to 10 feet....

GINKGO (Kew Tree.)

-BILOBA (Maiden Hair Tree.) A tall, sparsely branched trce with fan-shaped leaves. They are especially valuable for solitary planting and are free from insect injury.

6 to 8 feet............75e 8 to 10 feet.........\$1.25 LARIX (Larch.)

-DECIDUA (European Larch.) A pyramidal, coniferous tree, remarkable for its beautiful, light green foliage in early Spring.

4 to 5 feet...........75 8 to 10 feet.......... $\$ 1.25$ -LEPTOLEPIS (Japan Larch.) When young the foliage is bright green, changing to a bright golden yellow in Autumn.

4 to 5 feet......... $75 \mathrm{c} \quad 8$ to 10 feet........ $\$ 1.25$ -LARICINA (American Larch, Tamarack.) A tree with horizontal branches, forming a narrow, pyramidal head; bark, reddish brown; leaves of a light green color.

4 to 5 feet.

8 to 10 feet............ $\$ 1.25$ TAXIDIUM (Cypress.)

DisTiCHUM (Deciduous Cypress, Bald Cypress.) A very tall growing tree, with light brown bark. Branches are erect, and form a narrow, pyramidal head. 5 to 6 feet.............\$1.00 each. TILIA (Linden.)

AMERICANA (American Linden, Basswood,) A beautiful rapid glowing tree, with large, broad leaves and fragrant flowers. It will thrive best in moist rich soil and is valuable for park and street planting: 7 to 9 feet................................

ULMUS (EIm.)

ANERICANA. One of the most majestic and graceful of our shade trees. It is very hardy, long-lived, rapid grower and drought resister. 8 to 10 feet........75c 10 to 12 feet....... $\$ 1.25$

\section{EVERGREENS}

We have several hundred kinds of Evergreens, many sizes, for most any use and purpose. If you do not find what you want in the list given, give us a description of what you want, and we will quote you the lowest possible price.

\section{JUNIPERUS (Juniper.)}

CHINENSIS var. PFITZERIANA. A tree forming a broad pyramid, with horizontally spreading branches. 2 to $3 \mathrm{ft} \ldots \ldots \ldots \ldots \$ 2.25$ -SABINA (Savin Juniper.) A low, wide-spreading, thickly branched evergreen shrub, rarely $10 \mathrm{ft}$. high. 15 to $18 \mathrm{in} . . . \ldots \ldots . \$ 1.50$ -VIRGIANA (Red Cedar.) This evergreen will attain a height of 100 feet. Spreading or upright branches and conical head.

2 to 3 feet..........\$1.00 3 to 4 feet..........\$1.50

-GLAUCA. A vigorous growing form of the Juniper; has biue foliage and is very desirable.

18 to 24 in ............\$2.25

2 to $3 \mathrm{ft} . \ldots \ldots \ldots \ldots . \$ 3.00$

\section{PICEA (Spruce.)}

-EXCELSA (Norway Spruce.) Rapid grower and graceful habits and dark green foliage. Valuable for shelter and windbreaks.

18 to 24 in............50c 2 to $3 \mathrm{ft} \ldots \ldots \ldots \ldots \ldots . \$ 1.00$

-ORIENTALIS (Oriental Spruce.) A slow-growing evergreen, with dark, glossy foliage. Holds its lower limbs for many years and cventually attains a height of 120 feet. 2 to 3 feet..........\$2.25

-PUGENS (Colorado Blue Spruce.) A handsome and very hardy tree of symmetrical habit. Foliage is light green, almost silvery.

18 to 24 in .............................................

-KOSTERI (Koster's Blue Spruce.) 'The best of the blue Spruces, is perfectly hardy and will thrive in any soil. The silvery-blue foliage makes it a very attractive tree.

2 to $3 \mathrm{ft} \ldots \ldots . \$ 5.00 \quad 3$ to $4 \mathrm{ft} \ldots \ldots . \$ 7.50 \quad 5 \mathrm{ft} \ldots \ldots . \$ 12.50$

\section{PINUS (Pine.)}

-AUSTRICA (Austrian Pine.) A very tall, massive tree, with heavy, spreading branches and stiff, dark green needles. Should be

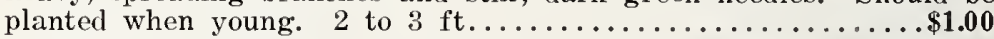

--STROBUS (White Pine.) A valuable, ornamental hardy pine, of rapid growth. Symmetrical when young and picturesque in old age. 2 to $3 \mathrm{ft} \ldots \ldots \ldots \ldots \ldots \$ 1.00 \quad 3$ to $4 \mathrm{ft} \ldots \ldots \ldots \ldots \ldots \$ 1.50$

-SYLVESTRIS (Scotch Pin.) This tree attains a great height with spreading branches and broad, round top. 2 to $3 \mathrm{ft} \ldots \ldots \ldots \$ 1.00$ THUYA (Arborvitae.)

-OCCIDENTALIS (American Arborvitae.) A rapid-growing tree with light green foliage. It can be trimmed to any desired height and is effective for grouping and formal uses.

2 to $3 \mathrm{ft} \ldots \ldots \ldots \ldots \ldots \ldots \$ 1.00 \quad 3$ to $4 \mathrm{ft} \ldots \ldots \ldots \ldots \ldots \ldots$ —var. PYRAMIDALIS (Pyramidalis Arborvitae.) Forms a tall slender column of densely branched, dark green foliage.

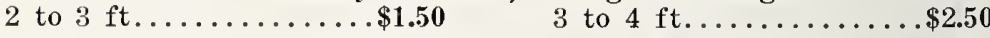
- var. SIBERICA (Siberian Arborvitae.) A pyramidal tree having bright green foliage the entire year. Lower and denser than the other varieties. 10 to 24 in......................... $\$ 1.00$ -var. GLOBOSA. A dense, dark green form of the Arborvitae, which grows naturally in globe form. Dwarf habit.

18 to 24 inches................................... $\$ 1.00$

—var. LUTEA (George Peabody's Golden Arborvitae.) This well known variety is handsome and desirable, also very useful in mass planting. 3 to 4 feet.........................\$3.00

- var. VERVAENEANA. Of smaller and denser habit than the type. Branches are small with yellowish foliage, which turns bronzy in winter. 2 to $3 \mathrm{ft} . \ldots \ldots \ldots . \$ 1.50 \quad 3$ to $4 \mathrm{ft} . \ldots \ldots \ldots . \$ 2.50$

-ORIENTALIS (Biota Orientalis.) A pyramidal tree of bright green foliage and compact form. It often attains a height of 25 feet 18 to $24 \mathrm{in} . \ldots \ldots \ldots \ldots \ldots \$ 1.00 \quad 2$ to $3 \mathrm{ft} \ldots \ldots \ldots \ldots \ldots 1.50$

-MONTANA var. Mughus (Dwarf Mountain Pine.) A very effective tree with dark brown branches and bright green leaves. It is broader than it is high and forms a dark, dome-shaped bush.

12 to $18 \mathrm{in} . . . \ldots \ldots \ldots . \$ 1.50 \quad 18$ to 24 in..........\$3.00

\section{RETINISPORA (Cypress)}

-PLUMOSA var. Aurea (Golden Japan Cypress.) One of the very few really golden evergreens, which makes a strong and effective contrast with the darker foliage of other evergreens. It is low-branched and very vigorous in growth. Unsurpassed for grouping effects.

18 to 24 in..........\$1.00 2 to $3 \mathrm{ft} . \ldots \ldots \ldots \ldots . \$ 2.00$

-PISIFERA (Swara Cypress.) A tall-growing tree with horizontal and somewhat pendulous branches. A well known and highly or-

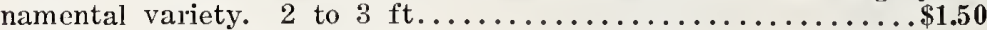

A full list of Roses and Perennials for spring planting sent on request 


\section{HARDY}

No home is complete without shrubs at these prices. No one can afford to be without the best that money can buy.

\section{ARALIA.}

-SPINOSA (Hercules' Club Angelica Tree. Devil's Walking Stick.) A shrub with stout, prickly stems and large leaves. The enormous clusters of flowers make it effective. Each 50c BERBERIS (Berborry.)

-THUNBERGII (Japanese Berberry.) Onc: of the valuable introductions received from Japan and is especially desired because of its low, dense, horizontal growth and bright aut umn colored leaves. It is quite hardy and the brilliant red berries are very attractive the entire Winter.

12 to $18 \mathrm{in}, \mathbf{1 5 c}$. 18 to 24 in. 20 c. 2 to $3 \mathrm{ft} .25 \mathrm{c}$

\section{BUDDLEIA.}

-VARIBILIS MAGNIFICA. (Butterfiy Bush.) A shrub of recent introduction, which blooms the first season, from June until frost. The blossoms are borne on long, tapering panicles of lilac-colored flowers, of miniature size. The flower head is often 10 inches long. The plant is perfectly hardy, yet we advise protecting the roots during the Winter months.

Each .....................4 40c CALYCANTHUS (Sweet Shrub.)

-FLORIDUS. An early-blooming shrub with handsome foliage and sweet-scented flowers of a dark reddish brown. The old-fashioned "shrub" of our grandmothor's garden. Each 40c.

CARYOPTERIS (Blue Spirea.)

-MASTICANTHUS. An ornamental plant grown for the lavender blue flowers, produced in late summer and autumn. Not entirely hardy as the plants often winter kill, almost to the ground, but new shoots are put forth and will flower the same season. 40c Each. CHIONANTHUS (White Fringe.)

-VIRGINICA. A very desirable, and Iarge growing shrub, bearing racemes of fringe-like white flowers late in May.

2 to 3 feet.....60 3 to 4 feet.....\$1.00 CLETHRA (Wweet Pepper Bush.)

-ALNIFOLIA. A native shrub, bearing spikes of scented yellowish-white flowers early in August.

40c Bach

\section{CORNUS (Dogwood.)}

-FLORIDA. A rearty, native shrub with handsome foliage and large, white showy flow-

ers which appear in May and before the leaves
are visible. are visible.

-VAR ELEGANTISSIMA. A very showy plant, having leaves marked with white.

40c Each.

-ALBA Var. Siberica (Siberian Dogwood) A tall shrub with bright, coral red branches, making them very ornamental for winter effect.

40 c Each.

\section{CYDONIA (Quince.)}

-JAPONICA (Japan Quince.) A common garden form, with scarlet-red flowers, which appear before the leaves and are followed by globular fruits.

CYTISUS.

-SCOPARIUS (Scotch Broom.) An erect low-bearing shrub, with yellow flowers and few leaves. A plant used for making brooms, by old Scottish people. It requires sunny locations and sandy soil.

40c Each.

\section{DEUTZIA}

-PRIDE OF ROCHESTER. A showy and early large-flowering variety that blossoms early in May, before the others. The shrub grows 6 to 8 feet high and has large, double white flowers.

\section{ORNAMENTAL SI}

-LEMOINEII. A spreading shrub, growing 3 feet in height, with pure white flowers, which appear in broad panicles. Very hardy.

$40 \mathrm{c}$ Each.

-GRACILIS. A handsome, bushy shrub of dwarf habit, with pure white blossoms appearing in May. Valuable for shrubbery borders.

\section{DIRRVILLA (Weigela.)} 40c Each.

-ROSEA. Vigorous growing shrub with large leaves. The flowers, which vary from white to pale pink, appear in May and June. 40c Each.

-HYBRID CANDIDA. A white flowering plant which is very desirable for the shrubbery border. 40e ivach

-NANA VARIEGATA. A dwarf shrub, with white flowers and variegated leaves. soc Each.

-EVA RATHKE. One of the low-growing species with carmine-red flowers, which appear in Spring and again in Autumn. $40 \mathrm{c} \mathrm{Each.}$ ELEAGNUS (Silver Thorn.)

-LONGIPES. A highly ornamental shrub with silvery foliage. Flowers are yellowishwhite and very fragrant. The scarlet fruit ripens in June or July.

$$
\text { EUONYMUS (Spindle Tree.) }
$$

-AMERICANA (Strawberry Bush.) An ornamental, upright shrub growing to 8 feet. The flowers appear in June, followed by attractive pink fruits.

$60 \mathrm{c}$ Each.

-ALATUS (Corky Bark.) An attractive ornamental shrub, valuable for its rustic effect. Flowers appear in May and June.

-EUROPEA. A large shrub, covered in Spring with bright yellowish leaves, changing to a beautiful scarlet shade in Autumn.

FORSYTHIA (Golden Bell.) $60 \mathrm{c} \mathrm{Each}$

-SUSPENSA. A highly ornamental, free flowering shrub, growing to 8 feet, with golden yellow flowers appearing in early Spring. The branches often droop to the ground and ake root.

35c Each.

-var. FORTUNEI. Similar to the Suspena but grows with upright or arching branches

\section{HIBISCUS (Althea)} 35c Each.

-SYRIACUS (Rose of Sharon.) One of the most common of the ornamental shrubs. also very hardy. With its variously-colored flowers and bright green leaves, it is very ef fective when planted as a hedge. 30c Each - ADRENS-Double violet. Tree form.

JEANNA d' ARC-Double white. Tree form.

RUBIS-Single red. Tree form.

SOUV. CHAS. BRETON-Single Violet. Tree form.

TOTUS ALBUS-Single white. Tree form.

AULISSIMA-Purple. Shrub form. form

BOULE DE FEU-Double red. Shrub

-MONSTRUS_Double red. form.

TOTUS ALBUS-Single white. Shrub

\section{KERRIA (Globe Flower.)}

-JAPONICA. A Japanese introduction which grows from 4 to $8 \mathrm{ft}$. in both height and breadth. The yellow flowers appear in early June, while in Autumn the leaves assume this color; then the light green branches of the Winter help make it attractive throughout the entire year.
SHRUBS

\section{HYDRANGEA.}

-VAR. STERILLIS (Hills of Snow.) A very showy variety, excellent for borders. Most all of the flowers are sterile. $40 \mathrm{c} \mathrm{Each.}$ -PANICULATA GRANDIFLORA. A hardy, ornamental shrub, having a dense, globose head and growing to 30 feet. Large, white flowers appear in August and September.

$40 \mathrm{c}$ Each.

-TREE FOKM. Similar to the above mentioned varieties, except that they are trimmed into the form of a tree. $\$ 1.00 \mathrm{Each}$ LONICERA (IIoneystekle)

-MORROWI. A decorative shrub that reaches 6 feet in height. The beautiful white flowers appear in May or June and are followed by red fruits which remain until late Autumn.

$40 \mathrm{c}$ Each.

-TARTARICA. This is an old-time fav orite shrub, which attains about 10 feet in height. The pink, white or creamy-colored flowers are produced in pairs. 40c Each -FRAGEANTISSIMA. Less hardy than other varieties and blooms very carly. A handsome half-evergrecn foligge and sweat seented flowers, which are nos very showy. $40 \mathrm{c}$ Eac'n. PHILADELPEIS (Syringa.)

-GRANDIFLORA. Large, white flowering shrub, growing to about 8 feet with spreading branches. Hardy and rapid grower. 40c Each.

-LFMOINEII. A giaceful shrub, with slender, arching branches. The sweet scented blossoms appear in short racemes of 3 to 7 inches in length.

-CORONARIUS (Mock Orange.) The blossoms are unusually fragrant, but less showy than many of the other species.

$40 \mathrm{c}$ Each.

-NANA AUREUS. Dwarf form of the Mock Orange, noted for its beautiful goldencolored leaves.

PRUNUS (Almond)

-AMYGDALUS vay. Plena. (Double flowering Almond.) Pink and white varieties. The double flowers appear in early Spring.

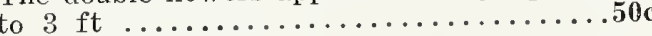

-TRILOBA. A most desirable bush. The double white flowers are solitary and mostly rose-colored. 2 to $3 \mathrm{ft} . \ldots \ldots \ldots \ldots \ldots \ldots$.

RHAMNUS (Buckthori)

CATHARTICA. A hardy orramental tree rrowing to about 12 feet and usually thomy. The greenish flowers appear in clusters and are followed by black berries. 4 to $5 \mathrm{ft} . .40 \mathrm{c}$ RHODOTYPHUS.

-KERROIDES. Sometimes called the White Kerria. An ornamental shrub usually from 3 to 7 feet high. It has bright green foliage, with white flowers in May or June and black fruits in the Autumn. 2 to $3 \mathrm{ft} . . .40 \mathrm{c}$ SPIREA

-ARGUTA. One of the most showy and free-flowering of the early spireas. Pure white flowers appear in May. Each 40c -BILLARDIA. A shrub growing six feet in height, having bright, pink flowers borne on long spikes. Each................... - Var. ANTHONY WATERER. A free flowering, compact shrub, of dwarf habit. An attractive variety that blooms the entire summer. Flowers bright crimson. Each.....40c -CALLOSA ROSEA. A low spreading shrub having purplish leaves and small pink flowers, appearing in July. Each.......40c -VAN HOUTTEI. Perhaps the hardiest and most beautiful of the early blooming Spirea. Grows to a height of 6 feet and is completely covered with pure white flowers in May. 2 to $3 \mathrm{ft} . . . .35 \mathrm{c} \quad 3$ to $4 \mathrm{ft} . . .40 \mathrm{c}$ 


\section{Spring Hill Nurseries Tippecanoe City. Ohio}

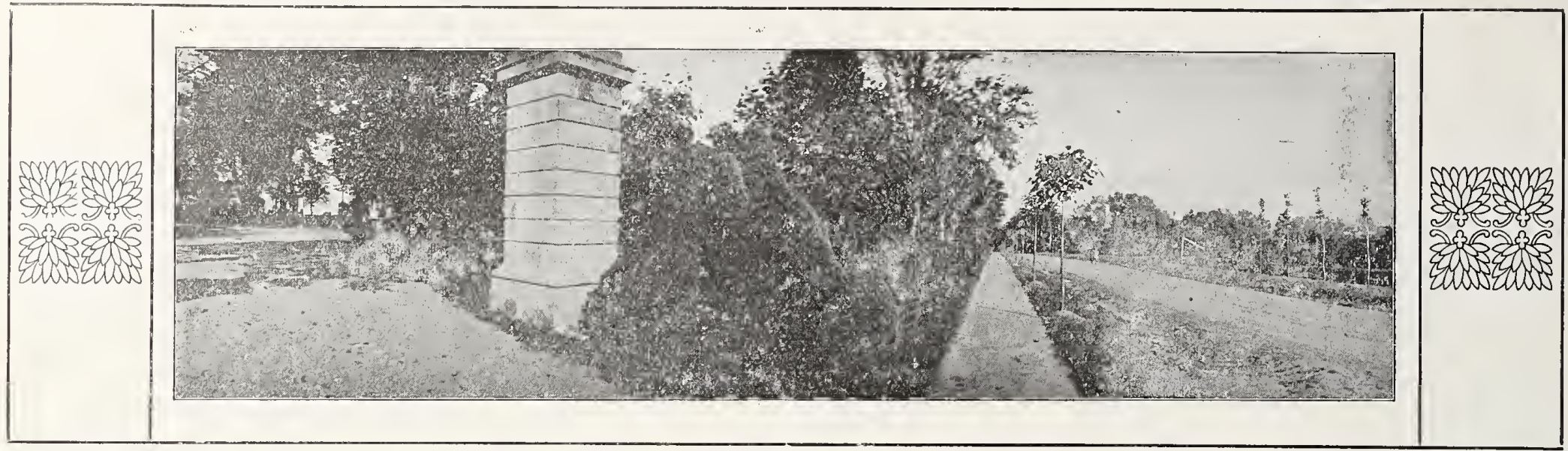

-THUNBERGII. An early flowering shrub growing to 5 feet and having bright green foliage, which changes to orange and scarlet in the Autumn. The pure white flowers, about one-third inch in diameter, appear in April or May. Each

\section{SYMPHORICARPUS.}

-RACEMOSUS (Waxberry.) A perfectly hardy shrub from 2 to 3 feet high that will thrive in most any soil. The rose-colored flowers appear in July and August and the white, waxy-like berries remain until late in the Autumn. Each ...............40c

-VULGARIS (Indian Currant, Coral Berry.) A compact bush, valuable because of its abundant and persistent red fruit. Each..40c

STEPHANANDRA.

-FLEXUOSA. In reference to the style of beauty, this plant is closely allied to the Spirea. The small, snow-white flowers which appear in June, are both numerous and showy. During early Spring the foliage is tinted red; deep, glossy green during the summer, changing to reddish-purple in Autumn. Each..40c

PRIVET-Ibota (Ligustrum Ibota.) Excellent for hedges, because of its extreme hardiness. Upright habit, with narrow green leaves and clusters of fragrant white flowers. $18-24$ in. per $100, \$ 7.50$. $2-3$ ft. per $100, \$ 10.00$

PKIVET-California (Ligustrum Ovalifolium.) Perhaps the best known hedge plant, having glossy, green foliage and pure white

AMPELOPSIS

-QUINQUEFOLIA Virginia Creeper. This is the most common of the climbers and thrives well in any soil. Leaves turn to bright scarlet and purple in the Fall; the dark blue berrics remaining quite late. Each.........40c -VEITCHII (Boston Ivy.) Once established, it grows rapidly and needs only an occasional trimming to keep it within bounds. The glossy green leaves turn to a brilliant orange-scarlet in the Autumn. Each....50

\section{CELASTRUS.}

-SCANDENS (False Bitter Sweet.) Very effective because of its bright-colored fruit, which usually remains throughout the entire Winter. Valuable for covering trellis-work, trecs or walls, and will grow in any soil.

Each
SAMBUCUS (Elder.)

-CANADENSIS Var. Aurea. A high-growing shrub, with beautiful golden foliage.

Each ........................ 40 -LACINIATA (Cut Leaf Elder.)An attractive variety with leaves cut in various patterns, also indented. Each.............40c SYRINGA (Lilac.)

The Lilacs are among the most popular and ornamental of the flowering shrubs. Some varietics are unusually fragrant, while others are scentless. Each ................75c - CHAS. DIX.

- CAERULEA SUPERBA. Clear blue.

- GEANT DES BATTAILLES. Single blue.

- JOSIKAEA. Single purple.

-LUDWIG SPAETH. Blackish red.

-MARIE LEGRAYE. Pure White.

-MAXIME CORNU. Double Rosy-lilac.

-MME. LEON SIMON. Rosy-lilac. TAMARIX (Tamarax.)

These plants are very beautiful for their coloring of bark, in Winter, and in summer for the light green, feathery foliage and large, loose panicles of purplish flowers.

-AFRICANA. An upright shrub growing to 8 feet and blooms in May. Each......40

\section{HEDGES}

flowers appearing in July. Can be pruned to a desired height. $18-24$ in. per $100, \$ 4.00$. 2 $3 \mathrm{ft}$. per $100, \$ 5.00$. $3-4$ feet per $100, \$ 7.00$.

PRIVET-Amoor River, (Ligustrum Amurense North.) An excellent hedge plant of upright growth and much hardier than the California Privet. Shiny foliage and white flowers. 18-24 in. per $100 \$ 10.00$. 2-3 ft. per $100 \$ 15.00$

\section{HARDY VINES \\ WISTERIA.}

-CHINENSIS. (Chinese Wisteria.) One of the best and most common of hardy climbels. It bears dense, drooping clusters of purplish pea-shaped flowers, in May. Each...40c

\section{CLEMATIS.}

- HENRYII. A free-blooming plant, hav ing creamy-white flowers which become fully expanded when exposed to the sun. Bloom through August and September. Each....75c

-CLEMATIS PANICULA'TA. The most common Clematic in American gardens. The small, fragrant, white flowers, which appear late in the season, malie it extremely showy.

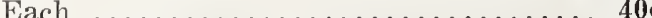

JACKMANII. A well known Clematis, having velvety purple flowers which are distinctly veined. When expanded, the blooms
-HISPIDA. A graceful shrub with upright branches and pink flowers, appearing in August. Each ................. 40c VIBURNUM (Snowball.)

-LANTANA (Wayfaring Tree.) A hardy shrub adapted to dry places and limestone soil Large, white flower clusters open in May and June and are followed by red fruits. Noted for its particularly soft and heavy foliage.

Each ..................... 50

-OPULUS. (High Bush Cranberry.) A handsome, native shrub attaining 12 feet Pure white flowers appear in May and June, followed by decorative fruits, which retain their bright scarlet color until the following Spring. Each ....................50

- Var. STERILE (Common Snowball, Guelder Rose.) The well known, common Snowball of the old-fashioned gardens. Besides the snow-white flowers, attractive in May, the foliage is also decorative and assumes a bright color in Autumn. Each .............50c - Var. PLICATUM (Japanese Snowball.) A highly recommended shrub, fine for specimen planting. The pure white flowers are borne in great profusion and the foliage is also abundant during the Summer and Fall. Each 75c
BERBERRY.-Japanese Berberry. One of the hardiest and best hedge plants, growing to 4 feet and will adapt itself to all conditions

We advise you to plant twelve to eighteen inch plants, which will develop as quickly as those of larger size and require less care, at the same time making a better fence. 12-18 in., 15c each. $18-24$ in., $20 \mathrm{c}$ each. $2-3 \mathrm{ft} .25 \mathrm{c}$ each.

measure 4 to 6 inches across. Each.....75c -MAD. ED. ANDRE. The nearest approach to a bright red Clematis and a very free-blooming variety. Each ..........75c LONICERA.

-JAPONICA var. Halliana (Hall's Japan Evergreen Honeysuckle.) A very ornamental vine, being adapted to covering walls, arbors, etc., and retain their leaves during the Winter. Flowers are white, turning to yellow and are very fragrant. Each .............25c

\section{PUERARIA.}

- HIRSUTA (Kudzu Vine.) A hardy vine with large, tuberous roots that make a vigorous growth. Vines will grow 40 to 60 feet in a season from a well-established root. Each $25 \mathrm{c}$ A Full List of Roses and Pelennials for Spring Planting sent on Request. 